the previous year, which was bad enough. The worst news was the loss within twelve days of the three distant water trawlers from Hull early in 1968. The losses of the trawlers highlighted the plight of the distant water fishing fleets. Yields and catches were on the whole good, but average values fell sharply particularly for wet fish from distant waters, and gross returns were reduced below already depressed levels.

One of the industry's troubles seems to be imports. There are no quantitative restrictions on imports of fish into Britain. This in itself may not necessarily lead to an increase in the volume of imports, but they may well unsettle the market. Fish is now a much more easily tradable commodity, thanks to the freezing facilities both on shore and at sea. Increased inshore landings of high quality fish have also had their effect on the markets for deep sea fish. The authority admits, however, that the market for distant water fish would not have been so vulnerable if the quality of the fish were better. The report states the obvious when it says that if trends are to be reversed, it is essential to land fish in fresher condition. The authority thinks that the best hope of doing this lies in boxing the catch at sea, with a view to shortening voyages drastically by fleeting operations. Some of the technical problems involved in such operations are being studied by the authority's research and development programme.

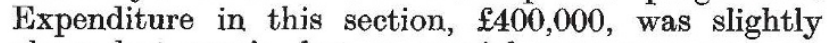
above last year's, but as special arrangements were made with regard to the costs of the exploratory voyage by a freezer trawler to the South Atlantic, expenditure in other parts of the programme actually fell. The programme covers all aspects of the fish industry from catching to marketing, and it includes research into the possibilities of marine fish farming. At the Port Erin hatchery in 1967 , the production target of some 55,000 plaice and 58,000 sole was achieved with good survival rates. At the loch enclosure at Ardtoe, the baby plaice introduced in 1965 reached a mean length of $24 \cdot 6 \mathrm{~cm}$ in 2.5 years; and the sole introduced to the warm water discharge at Hunterston power station in 1966 reached minimum market size in 18 months, about half the time it normally takes.

The main effort at the moment in the research and development programme, however, is in the development of fishing vessels and their equipment. To carry out this part of the programme the authority set up an industrial development unit. The year's work of this body in the fields of mechanization and manpower at sea, increasing productivity, cost effectiveness of vessels and machinery, and quality, variety and acceptability of the fish is outlined in the report. The authority wishes that it had more money to enlarge the programme. The year under review was the third successive year that it had a deficit. "It has become obvious that additional revenue must be made available to the authority if its services are not to be cut."

\section{Infant Science}

"Oceanography is still in its earliest stages; to expect immediate returns is to expect Johnny to run before he can walk." This statement was made by the minister responsible for most of the oceanographic research being done today in Britain, Mrs Shirley Williams, Secretary of State for Education and Science, during a visit to the National Institute of Oceanography last Monday. She added that Britain must have more fundamental research in this field without expecting immediate practical applications and that the Government planned to greatly increase the funds available.

The institute was set up in 1949 primarily because of naval interest in wave research. This was the beginning of oceanographic research in this country; there are now 189 people working at this institute alone. In 1965 the responsibility for the institute was shifted from the National Oceanographic Council to the Natural Environment Research Council.

A new collecting net that can be opened and closed using an acoustic control was demonstrated to the minister. The net is opened when an acoustic signal triggers the release of a bolt, thereby enabling scientists to collect samples from only one depth. Most of the biological work of the institute is concerned with the ecology of marine animals, though work is also being carried out on aspects of animal migration, especially in the vertical plane.

The evidence for continental drift in the eastern North Atlantic is now quite well established, but problems still remain. One interesting theory is that the Bay of Biscay resulted from the anticlockwise rotation of Spain. These and similar theories are being investigated in conjunction with university departments.

\section{Defence Research}

INDUSTRY should play a much greater part in the planning and running of defence research. This recipe for success was presented to the Select Committee on Science and Technology by the body most likely to benefit from its adoption, the Confedoration of British Industry. The witnesses from the CBI, headed by Sir Denning Pearson, the new chairman of Rolls-Royce, suggested that research was carried on in government establishments under "grossly exaggerated security conditions". Later, though, Sir Denning seemed to turn the argument on its head by criticizing the way in which the work on carbon fibre reinforced plastics at Farnborough had been published rapidly (in Nature). "Early publication undoubtedly alerted the world," he declared, but suggested that the damage was done not so much by the content of the paper as by the evidence it gave that Farnborough was hard at work on the new material.

The present system of doing defence research, Sir Denning said, was complicated, and led to delays. In a blessedly short memorandum, the CBI picked out the "interwoven committee structure" of the Ministry of Defence for particular criticism. Projects should be managed by a single man, with full financial responsibility, though the CBI recognized that this might be difficult to organize in the Civil Service. Sir Denning thought that the difficulties of recruiting talented project managers had been exaggerated-Rolls-Royce, he said, always managed to find them. He went on to suggest that, in Britain, an industry's ability to compete internationally could be graded on the basis of the ratio of research work in the industry to that in government establishments. Too often, he said, cuts in the strength of the armed services had not been matched by similar cuts in the establishments. "There must be room for substantial cuts," he said. But establishments had a life of their own, and were very difficult to reduce 